\title{
CERAMBYX GIGANTEUS.
}

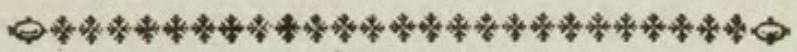

ChARACTER GeNERICUS.

Antenna fetaceæ.

Palpi quatuor.

Thorax fpinofus aut gibbus.

Elytra linearia.

Lin. Syft. Nat. Gmel. p. 1814.

CHARACTER SPECIFICUS, छc.

CERAMBYX thorace utrinque tridentato, corpore nigro, elytris ferrugineis, antennis brevibus. Lin. Syft. Nat. Gmel. p. 1816.

PRIONUS giganteus.

$$
\text { Fab.Spec. inf. 1. p. } 206 .
$$

Depingitur Cerambyx giganteus magnitudine naturali. Americam auftralem inhabitat, phyficifque Europæis paucis abhinc annis innotuit. A Domino Drury in elegantiffimo opere de infectis exoticis eximie exprimitur, nec non a Domino Daubenton in opere cui titulus Planches Enluminées. Color eft obfcure caftaneus, feu terreo-fufcus, thorace paulum nigriore. Elytra, feu alarum thecæe exteriores, quodammodo fcabra funt : antennæ breviffimæ. 


\section{GREAT CERAMBYX.}

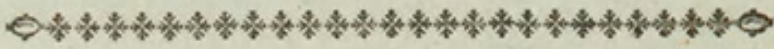

\section{GENERIC CHARACTER.}

Antenne fetaceous.

Thorax either fpinofe or gibbofe.

Palpi four.

Wing-Cajes long or linear.

SPECIFIC CHARACTER, छC.

Black CERAMBYX, with ferruginous wingcafes, thort antennæ, and thorax tridentated on each fide.

Le THUSTE de Cayenne.

$$
\text { Pl. Enl. 64. } f .2 \text {. }
$$

The great thort-horned CERAMBYX.

The Cerambyx giganteus, reprefented in its natural fize on the annexed plate, is a native of South America, and was introduced to the notice of European naturalifts fome few years backwards. It has been extremely well figured by Mr. Drury, in his elegant work on exotic infects; as alfo by Monf. Daubenton in his Planches Enluminées. Its color is a uniform dull chefnut, or earthy brown: the thorax is fomewhat darker or blacker than the other parts: the elytra or wing-cafes are of a roughifh furface, and the antennze are remarkably thort. 


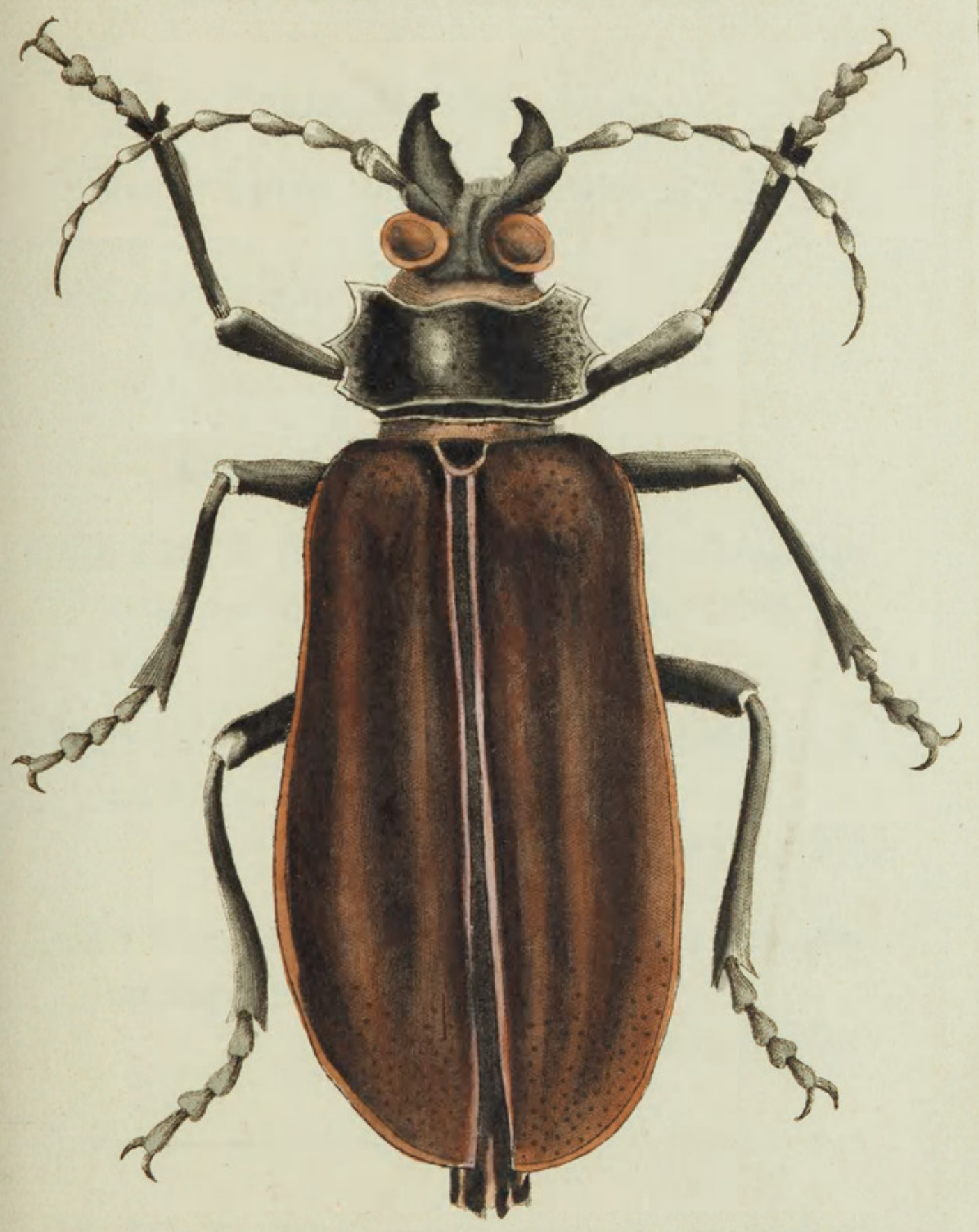




\section{$2 \mathrm{BHL}$ Biodiversity Heritage Library}

Shaw, George. 1797. "The Great Cerambyx, Cerambyx giganteus [PI. 280]." The Naturalist's Miscellany 8(XCI), https://doi.org/10.5962/p.310823.

View This Item Online: https://www.biodiversitylibrary.org/item/276320

DOI: https://doi.org/10.5962/p.310823

Permalink: https://www.biodiversitylibrary.org/partpdf/310823

\section{Holding Institution}

Museums Victoria

\section{Sponsored by}

Atlas of Living Australia

\section{Copyright \& Reuse}

Copyright Status: Public domain. The BHL considers that this work is no longer under copyright protection.

This document was created from content at the Biodiversity Heritage Library, the world's largest open access digital library for biodiversity literature and archives. Visit BHL at https://www.biodiversitylibrary.org. 